\title{
Beyond Brain Drain: The Dynamics of Geographic Mobility and Educational Attainment of B.C. Young Women and Men*
}

\section{LESLEY ANDRES}

The University of British Columbia

\section{AARON LICKER}

The University of British Columbia

\section{ABSTRACT}

In recent years, the topic of "brain drain" has gained considerable attention, both in public and intellectual spheres. Despite the media frenzy, few data sets and related studies exist to examine the nature and extent to which brain drain occurs. The purpose of this study is to extend the scope of the way we think about "brain drain," both conceptually and analytically, by examining the geographic migration and mobility patterns over a 10 year period of a large sample of young adults from British Columbia. Through analyses of detailed longitudinal questionnaire data, we examine geographic mobility patterns in relation to (a) B.C. college region of origin, (b) post-secondary educational completion patterns, and (c) gender. Findings reveal that migration patterns are both gendered and geographically complex. Our findings support the claim that brain drain to the U.S. is a mere trickle, not a flood. When examining gender differences of respondents living in the U.S. and outside North America, the vast majority of women who live outside of Canada have earned university 
credentials, which suggests that global mobility for women appears to be related to university degree completion. These findings challenge the narrow definition of brain drain as simply a Canada - U.S.A. issue where Canada's "best and brightest" are lured from Canada and invite us to consider the implications of intra- and extra-provincial brain drain (and gain), primarily within the confines of Canada.

\section{RÉSUMÉ}

Au cours des dernières années, l' "exode des compétences" a reçu une attention considérable dans les sphères publiques et intellectuelles. En dépit de la frénésie des médias, il y a peu de données et d'études pertinentes qui examinent la nature et l'ampleur de ce phénomène. Le but de cette étude est de réviser le concept de « l'exode des compétences » en examinant des modèles géographiques de migration et de mobilité d'un groupe de jeunes adultes de la Colombie-Britannique au cours d'une période de dix ans. La présente enquête longitudinale examine des modèles géographiques de mobilité par rapport (a) à la région d'origine à l'intérieur de la Colombie-Britannique, (b) aux parcours d'études post-secondaires, et (c) au genre. Les résultats indiquent que les modalités de migration sont géographiquement complexes et différentiées par le genre. Nos résultats soutiennent la thèse que l'exode des compétences de la ColombieBritannique vers les États-Unis représente un ruissellement et non une inondation. En examinant les différences de genre des répondants établis aux États-Unis et à l'extérieur de l'Amérique du Nord, la grande majorité des femmes qui vivent en dehors du Canada ont obtenu des diplômes universitaires, ce qui suggère que la mobilité globale des femmes est liée à l'obtention d'un diplôme universitaire. Ces résultats défient la définition étroite de l'exode des compétences comme tout simplement un problème limité aux plus capables des Canadiens qui sont leurrés par les Etats-Unis. La présente étude nous invitent donc à considérer les implications des mouvements intra et interprovinciaux, principalement ceux à l'intérieur du Canada, pour une meilleure compréhension de ce phénomène. 


\section{INTRODUCTION}

In recent years, the topic of "brain drain" has gained considerable attention both in public and intellectual spheres. Headlines such as "Brain Drain Study Finds the Best are More Likely to Leave" (Leblanc, 1999), "Will Surgery Fix this Brain Drain" (Oleck \& Weber, 1998), "Battling the Brain Drain" (Johnson, 1998), and "It's Taking Less to Lure Canadians South: B.C. Study" (Beauchesne, 2001) have fuelled the debate that Canada is losing its most highly educated workers to the United States.

Despite the media frenzy, few data sets and related studies exist to examine the nature and extent to which brain drain occurs. Three data sets - the Personal Income Tax Data File, the Census Reverse Record Check, and the U.S. Current Population Survey-have been employed to examine movement by Canadian workers to the U.S. (Finnie, 2001). However, Zhao, Drew, and Murray (2000), point out that each of these sources of data suffers from reliability problems and provides, at best, broad estimates of emigration to the U.S. ${ }^{1}$ Despite such limitations, results from studies employing these data have been reported widely. Finnie (2001) reports that tax records reveal that "the number of tax filers leaving Canada to all destinations has increased steadily in recent years, from about 15,360 in 1991 to 28,870 in 1997 , with an average of about 21,700 per year over this period" (p. 3). Analyses of the Reverse Record Check data suggest that " 178,000 people left Canada to go to the U.S. between 1991 and 1996, and past experiences indicate that 126,000 of these would be expected to remain permanently in the United States and 52,000 to return to Canada" (p. 3). Zhao et al. (2000) add that tax filer data reveal that those emigrating to the United States represent only $0.1 \%$ of tax filers and only $1 \%$ of those with the highest levels of education. Of this small proportion of Canadians, two-thirds were in the 25-44 age range. Analyses of the Current Population Survey reveal that $49 \%$ of those emigrating to the United States between 1994 and 1999 possessed university degrees. Although representing only $0.1 \%$ of tax filers, movers were "seven times more likely as all tax filers to have incomes of over $\$ 150,000$ (4.0\% of 
movers versus $0.6 \%$ of all tax filers) [and] five times more likely to have incomes between $\$ 100,000$ and $\$ 149,000$ (4.0\% of movers versus $0.9 \%$ of all filers)" (Zhao et al., 2000, p. 14).

One recent study was designed and conducted specifically to examine the extent of brain drain to the United States by educated Canadians. In a joint effort by Statistics Canada and Human Resources Development Canada (HRDC), 531 respondents to the 1995 National Graduate Survey (NGS) who had moved to the United States between 1995 and 1997, were interviewed in March 1999 to determine the following: level and field of study, activities prior to moving to the U.S., reasons for moving, work experiences in the U.S., plans for the future, and individual characteristics ${ }^{2}$ (Frank \& Bélair, 1999, p. 2).

Overall, only $1.5 \%$ of 1995 post-secondary graduates moved to the United States between 1995 and 1997. However, those with masters and doctoral degrees were overrepresented; $12 \%$ of those with Ph.D.s were among those who emigrated south. Compared to those who remained in Canada, more graduates in the fields of health, engineering, and applied sciences moved to the U.S. The proportion of women (50\%) who emigrated was slightly less than that of men $(57 \%)$; however, the vast majority of those with credentials in engineering, mathematics, and physical sciences were men. Over half (57\%) of respondents moved for work, $27 \%$ reported moving for education, and $17 \%$ indicated that marriage and relationships were the single main reason they moved. Eighty-four percent of those who moved for education were men, and $86 \%$ of those who moved for relationship reasons were women. Women and men were equally likely to move for work-related reasons. However, as Frank and Bélair (1999) point out, "somewhat surprisingly, given the debate and media coverage of this issue, an insignificant proportion of graduates explicitly said that lower taxes in the U.S. were a factor that attracted them to work there" (p. 15), which supports the claim by others that Canadians are attracted to the United States for job opportunities, and not for reasons of tax reductions (CAUT, 1999b; Day \& Winer, 1994; Michalos, 1997).

Based on the findings of this and other studies, conclusions have been drawn such as "emigration to the United States remains small by 
historical standards and small relative to the stock of workers in the Canadian labour force" (Zhao et al., 2000, p. 14), migration to the U.S. is a "trickle and not a flood" (CAUT, 1999, p. 1), and is "small in absolute terms. ... In historical terms, the flows are the smallest they have been since 1851" (Murray, 2000, p. 6). According to Johnson (2000), much, if not most, of the discussion about brain drain has been driven by a "lack of any empirical data that would account for what appears to be the hysterical approach that has brought to bear upon this topic" (p. 9). Others have commented that although the issues are complex (Helliwell, 2002; Kesselman, 2001; Murray, 2000; Zhao et al., 2000), the debate has been cast very narrowly (Torjman, 2000) and the discourse remains compartmentalized (Shakir, 2000).

The term "brain drain" and related studies conducted within the Canadian context is delimited to migration of Canadians to the United States. Even when data are available, analyses have not typically been extended to monitor other types of migratory behaviour (for one exception, see Anisef, Axelrod, Baichman-Anisef, James, \& Turrittin, 2000). In the United States, Europe, and Australia, much attention has been paid to international "brain drain" (Bell et al., 2002; Mahroum, 2000; Morokvasic, 1996) as well as regional, state, or country level migration (Bell, 1996; Dahl, 2002; Garasky, 2002; Kodrzycki, 2001; Partridge \& Rickman, 1999; Stimson \& Minnery, 1998; Sweeney \& Konty, 2002; Voss, Hammer, \& Meier, 2001). Only a few studies have been carried out at the civic or local level (Cromartie, 2000; Wright, Ellis, \& Reibel, 1997). In Canada, migration occurs both intra-provincially and extra-provincially. The frequency of moves from and to given destinations provides insights into the drains and gains that various regions may be experiencing. The purpose of this study is to extend the scope of the way we think about "brain drain," both conceptually and analytically, by examining the geographic migration and mobility patterns over a 10 year period of a large sample of young adults from British Columbia. First, existing literature on different approaches to this topic will be summarized.

Studies in the United States, Great Britain, and Australia have addressed the study of migration or "brain drain" from different perspectives. 
Some studies approach the problem from primarily an occupational perspective (Borjas, Freeman, \& Katz, 1996; Detang-Dessendre \& Molho, 1999; Mahroum, 2000; Partridge \& Rickman, 1999; Voss et al., 2001) whereas others view migration as an educational issue (Cromartie, 2000; Kodrzycki, 2001; Morokvasic, 1996) or examine this phenomenon in relation to familial factors (Garasky, 2002; Mulder \& Clark, 2000). A few studies attempt to integrate various socio-economic indicators, including various "push" and "pull factors," to explain migration (Garasky, 2002; Kodrzycki, 2001; Mulder \& Clark, 2000; Stimson \& Minnery, 1998).

Although a considerable amount of anecdotal evidence concerning "brain drain" has been exploited by the media and policy makers in Canada, the U.S., the U.K., and Australia, very few studies exist that employ valid data to explain migration patterns. Many authors use aggregated census data to understand migrational movement (Bell et al., 2002; Bell, 1996; Boyle \& Flowerdew, 1997; Voss et al., 2001; Wright et al., 1997). Although such data are complete and contain much in the way of socioeconomic information, they do not allow for time series analyses (Bell et al., 2002; Treyz, Rickman, Hunt, \& Greenwood, 1993). In addition, the level of aggregation provides generalized information that is not useful for analyses of migration to and from smaller communities (Cromartie, 2000). For these reasons, the use of longitudinal data sets is becoming increasingly common and desirable for research on migration. In the United States, the National Longitudinal Study of Youth (NLYS) is used by many demographers to explain the effects of "brain drain" (Cromartie, 2000; Garasky, 2002; Kodrzycki, 2001). The NLYS is a comprehensive longitudinal study following the behaviours of a large sample of individuals spanning numerous age groups and geographical areas. Studies use the NLYS to measure the effects of gender, race, climate, education, urban/ rural locations, and employment as factors affecting the so-called "brain drain" effect (Cromartie, 2000; Garasky, 2002). A few studies (Buck \& Scott, 1993; Mulder \& Clark, 2000; Whittington \& Peters, 1996) employ the Panel Study of Income Dynamics (PSID), claiming that this source of data has better measures of parental resources and more birth cohorts available for study. For an accurate assessment of geographic mobility 
within a Canadian context, analyses of an integrated longitudinal data set that contains demographic, economic, educational, and social information on a large sample of individuals belonging to a single cohort is required.

Various types of analyses have been used in the study of migration. Descriptive statistics are most often used to show proportions of individuals with various attributes in various aggregate regions (Cromartie, 2000; Garasky, 2002; Mahroum, 2000; Morokvasic, 1996; Stimson \& Minnery, 1998; Voss et al., 2001). Other researchers have employed various types of regression techniques to analyze the relationship of various factors on migration (Borjas et al., 1996; Boyle \& Flowerdew, 1993; Kodrzycki, 2001; Mulder \& Clark, 2000; Treyz et al., 1993; Wright et al., 1997).

In most studies, there is a lack of modeling of what is primarily a spatial problem. Few studies have attempted to reconcile demographic data to its spatial phenomena (Dorigo \& Tobler, 1983) and most have not used Geographic Information Systems (GIS) when studying migration patterns. Adequate technology exists to integrate disparate types of data into one geo-spatial database. The current advantage of Geographic Information Systems applications is their capacity to accommodate multiple types of spatial data over numerous time frames due to overlay capacities (Dorigo \& Tobler, 1983). GIS also allows for the use of a sophisticated suite of geostatistical models and processes that can be used to determine the factors affecting local and regional mobility, to various spatial locations.

\section{Purpose}

The aim of this study is to employ Geographical Information Systems techniques to map the intra- and extra-provincial migration patterns, over a 10 year period, of a large sample of British Columbia young adults. By incorporating longitudinal data containing a comprehensive set of demographic, educational, and attitudinal data into one geo-statistical framework, migration patterns can be determined for young adults within and outside of British Columbia by gender, college region, and educational attainment. Specifically, the following questions will be addressed: What are the geographic migration and mobility patterns of the B.C. 
Class of 1988? Do these patterns differ by gender and college region? When examining the migration patterns of young adults over a 10 year period of time, is educational attainment an influential factor?

\section{Research Design}

To address these questions, longitudinal data are employed from the Paths on Life's Way Project of British Columbia young adults. The Paths on Life's Way Project is the only longitudinal study of its kind in British Columbia and one of the few longitudinal studies of young adults in Canada (Andres, 2002a, 2002b, 2002c, 2002d). The research, now spanning 10 years, provides a detailed account of individuals' lives, choices, and postsecondary education and work experiences across different points in time since high school graduation in relation to changing economic, social, and cultural conditions. Specifically, the data base contains information on education, occupation, and geographic mobility on a provincially representative sample of over 1,000 individuals from the B.C. high school graduating Class of 1988 collected by mail questionnaires in 1989, 1993, and 1998.

The first phase of the study consisted of a 1989 postal survey focusing on the educational choices made by a large systematic sample of 1988 high school graduates $(n=5,345)$. The study included postsecondary participants and non-participants from all 75 school districts in British Columbia. High school and post-secondary records, providing demographic, academic achievement, and institutional information, were linked to the questionnaire data. In 1993, a second follow-up of the 1989 study was carried out. Individuals who had completed the first survey were contacted by mail, and a total of 2,030 completed the 1993 follow-up survey. The third follow-up, conducted in 1998, resulted in the return of 1,055 completed surveys. ${ }^{3}$

The central focus of this paper is to trace geographic mobility patterns over a 10 year period of time. We are interested in geographic mobility patterns in relation to (a) college region of origin, (b) post-secondary educational completion patterns, and (c) gender. The first variable of interest is college region of origin. British Columbia is organized into 
15 college regions (see Map A) which will be used to identify respondents' home regions. Mobility to and from these regions, as well as to other provinces and countries, is the primary focus of the analysis.

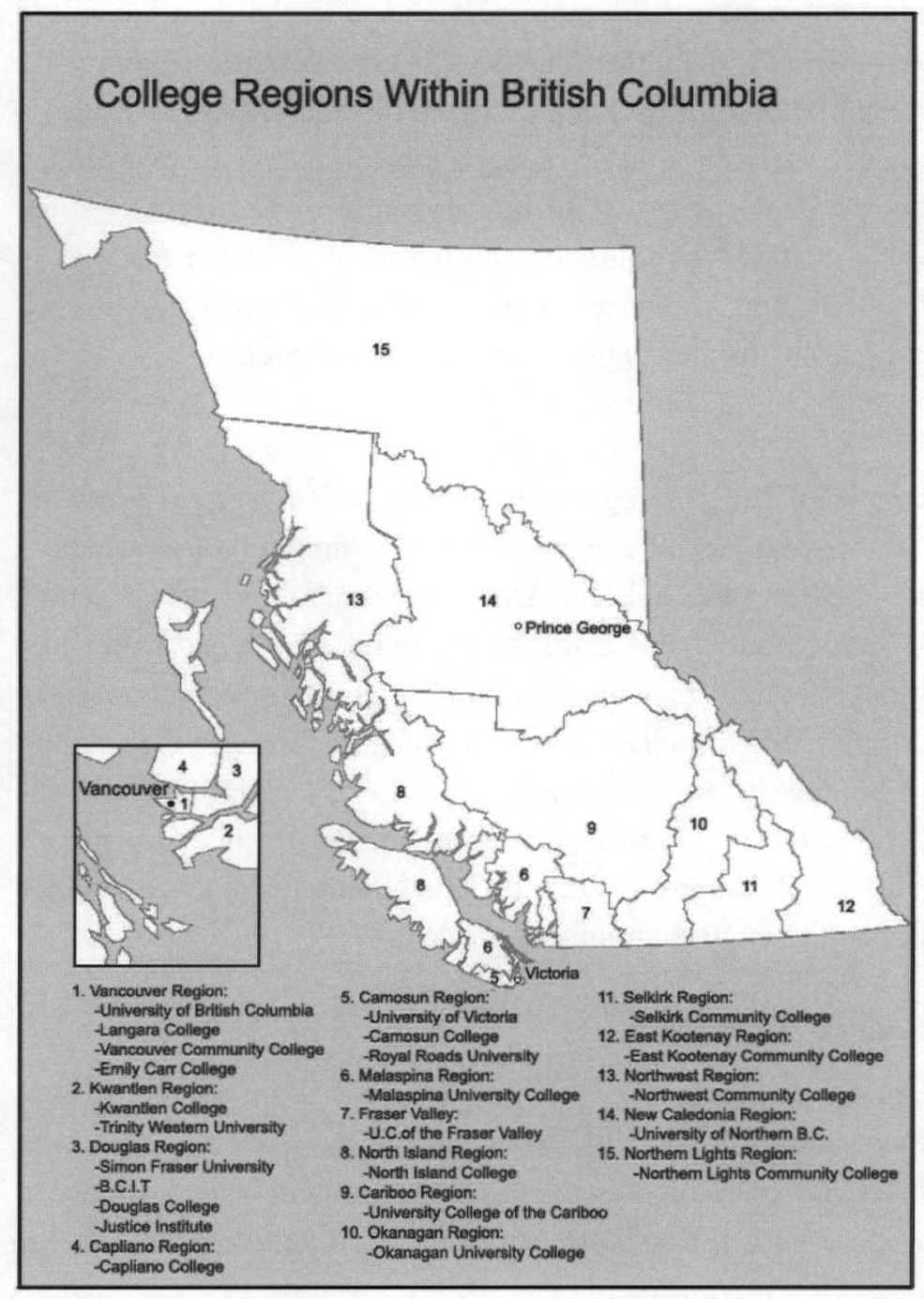

Figure 1: Map A - College Regions Within British Columbia

Electronic versions of the maps can be found at:

http://www.edst.educ.ubc.ca/paths/Beyond_Brain_Drain.pdf

The Canadian Journal of Higher Education

Volume XXXV, No. 1, 2005 
Post-secondary completion rates of respondents are defined as the highest level of educational attainment by 1998 (10 years following high school graduation). Educational attainment levels used in this study include either non-university completion (i.e., non-participation in the post-secondary system, non-university completion, or non-completion of university studies) or completion of a bachelor's degree or higher. Gender is also a key independent variable. Finally, geographic mobility was determined by asking respondents of the 1998 questionnaire to answer a detailed question which included the following: all places of residence since 1988 (i.e., community name, province, country), length of residence at each location, and reasons for leaving each location (open ended).

\section{Results}

This sample of B.C. young adults is very well-educated. Forty-six percent of women and $49 \%$ of men have earned a minimum of a bachelor's degree as their highest educational credential 10 years following high school graduation. Map 1 portrays the distribution of young men and women by college regions of origin in British Columbia. The largest proportion of respondents originated from the Okanagan college region and the smallest proportion from the remote Northern Lights college region. In Map 1, the destinations of the Class of 1988 are also portrayed. As of 1998, respondents lived in 35 different locations - within B.C., in other parts of Canada, in the United States and elsewhere around the world.

\section{Mapping Geographic Mobility}

The data employed in this analysis are spatial in nature because they document the movements of 1,046 high school graduates over both time and space. By tracking how these young adults moved, a variety of migrational effects for this sample can be profiled and compared to the results of other "brain drain" studies.

The migrational patterns of the sample were aggregated at the college region level. Although college regions in British Columbia do not necessarily represent real world agglomerations, as a level of geographic 

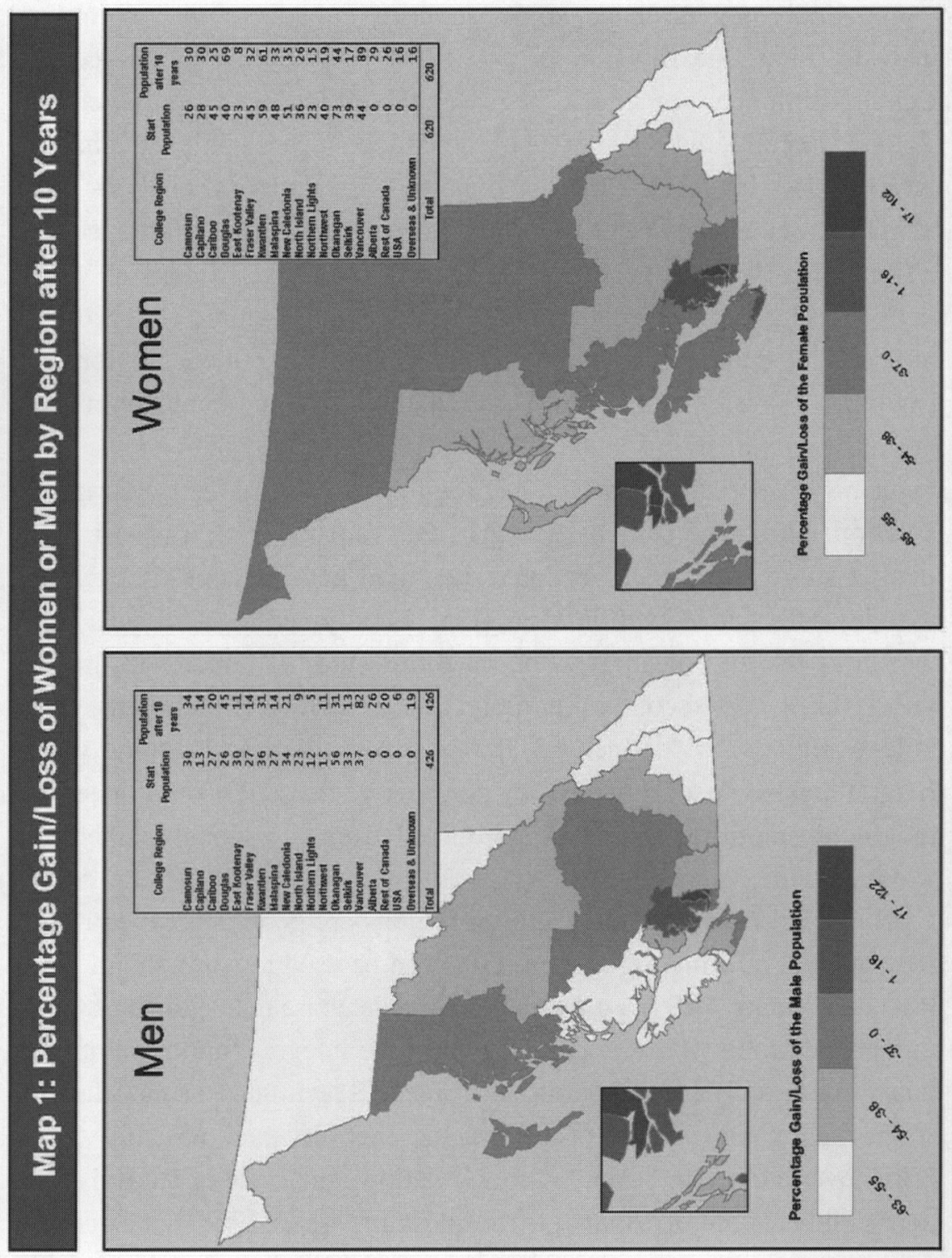

Figure 2: Map 1 - Percentage Gain/Loss of Women or Men by Region After 10 Years 
aggregation, they do have some qualities conducive to longitudinal analysis. First, the division of the 1,046 respondents across college regions, although not equal, is reasonably distributed across college regions. ${ }^{4}$ Second, the boundaries of the college regions have not changed over the past 10 years, which is important for temporal analysis when comparing geographic entities over time. Third, each of the college regions is fairly homogenous. That is not to say that all persons within any particular college region have the same values, ethnic backgrounds, or levels of educational achievement. Rather, the college regions are groupings of various regions of B.C. in an intuitive geographical manner. Hence, a person living in the Northwest region will likely have more contact with persons in his or her region, because of its geographical isolation. Similarly, persons living in the Vancouver region will likely identify more with other Vancouverites than with persons living in the Douglas (Burnaby/Coquitlam) region. Finally, college regions were chosen as the unit of analysis because this study is concerned, in part, with level of post-secondary participation by British Columbians. Since college regions are defined by the post-secondary institutions within them, it makes sense from a policy perspective that questions concerning geographic mobility should be addressed from a regional, rather than province-wide perspective.

Since British Columbia's college regions are geographical entities, a geographical information system (GIS) can be used to study the mobility of its inhabitants. GIS is a combination of a database management system, a graphical production suite, and the ability to integrate multiple forms of data into a visually appealing format. Thus, GIS facilitates the visualization of the nature and extent of geographic mobility and possibly "brain drain" over a ten year period. Also, GIS allows the scale of analysis to be consistently altered in response to the questions asked. That is, the question can be approached from a civic level, regional level, or provincial level. For the purposes of this study, geographical mobility will be examined by college region. 


\section{Profiling the Sample}

First, the destinations of the Class of 1988 are profiled as of 1998 by college region of origin (Map 1). This cohort moved around both British Columbia and beyond. However, 10 years following high school graduation, only $13.3 \%$ were located extra-provincially. Alberta gained the largest number of immigrants; by 1998,55 individuals or $5.3 \%$ of the cohort lived in Alberta. Twenty-two individuals (2.1\%) moved to the United States, and another $2.3 \%$ moved to Ontario. These three destinations (Alberta, Ontario, and the U.S.) accounted for the migration of $9.7 \%$ of the sample after ten years. The next largest recipient of immigrants was Saskatchewan with seven individuals or $0.7 \%$. Other areas that gained immigrants were Quebec, Manitoba, Japan, the United Kingdom, which each had four ex-B.C. residents after a ten year period. Australia attracted one individual, while the Yukon, Newfoundland, and Nova Scotia acquired two each. Other regions as varied as Bosnia, Honduras, South Korea, Chile, the Northwest Territories, and Cambodia gained a total of six persons. Finally, 19 persons or $1.8 \%$ of the population did not record their current address on the last survey and thus were considered to live in places unknown.

Levels of intra-provincial migration were examined by college regions of origin. This was accomplished by taking the difference between the current number of individuals within a college region and the original number, and then expressing this difference as a percentage of the original residents. The percentage of gain or loss by region and gender is displayed on Map 1. For the most part, urban regions experienced higher levels of immigration than emigration, resulting in population gains. For instance, the Vancouver region experienced a $122 \%$ gain in the number of males within the region and a $102 \%$ gain in females. Other parts of the Greater Vancouver Regional District (GVRD) and the Camosun region experienced gains or slight losses with few gender differences. Rural college regions lost large proportions of those originating from these areas. The East Kootenay Region was the largest loser, with a 59\% loss for males and $85 \%$ loss for females. At the B.C. level, movement occurred from rural to 
urban areas. These preliminary results raise the following questions: What are the mobility patterns of B.C. young adults relative to their college regions of origin and current locations of residence? What is the level of educational attainment of outgoing individuals compared to those who stayed? The first question will be dealt with in the next section.

\section{Geographic Mobility from College Region of Origin}

Geographic mobility of this sample by region of origin varied widely by gender and exhibited several distinct trends. To understand the mobility patterns of this cohort, an index of mobility was created which is a tabulation of the mean number of all moves that individuals took to arrive at their current location of residence. This index was broken down by region and gender and is displayed on Map 2. Moves consist of reported movements between places as reported by respondents on the 1998 questionnaire. Since moves were agglomerated at the community level, a move between Kelowna and Penticton would consist of one move (from one community to another), while a move between Kitsilano and Point Grey would not (a move within the same community). In total, women made 2,753 moves for an average of 4.5 moves, and men made 2,006 moves, averaging 4.8 moves. The number of moves ranged from 0 to 22 . The most mobile group were males originating from the Northern Lights region. They moved an average of 8.7 times over 10 years. Women from the same region moved an average of 4.4 times. For all but two regions (Malaspina and Douglas), men were equally or more mobile than women. Only in the Northern Lights college region was this difference so pronounced. In most areas, the difference between the means was only in the order of one move.

Perhaps more important were the movement differences of residents originating from rural versus those from urban college regions. For men and women in four of the five urban regions (Vancouver, Douglas, Capliano, Kwantlen), the average number of movements did not exceed 4. For most rural areas, with the exception of Malaspina for the men, and Northern Lights and Cariboo for women, the number of movements between places did not dip below 5 . Hence, individuals originating in rural regions were more mobile than their peers in urban regions, regardless of gender. This 


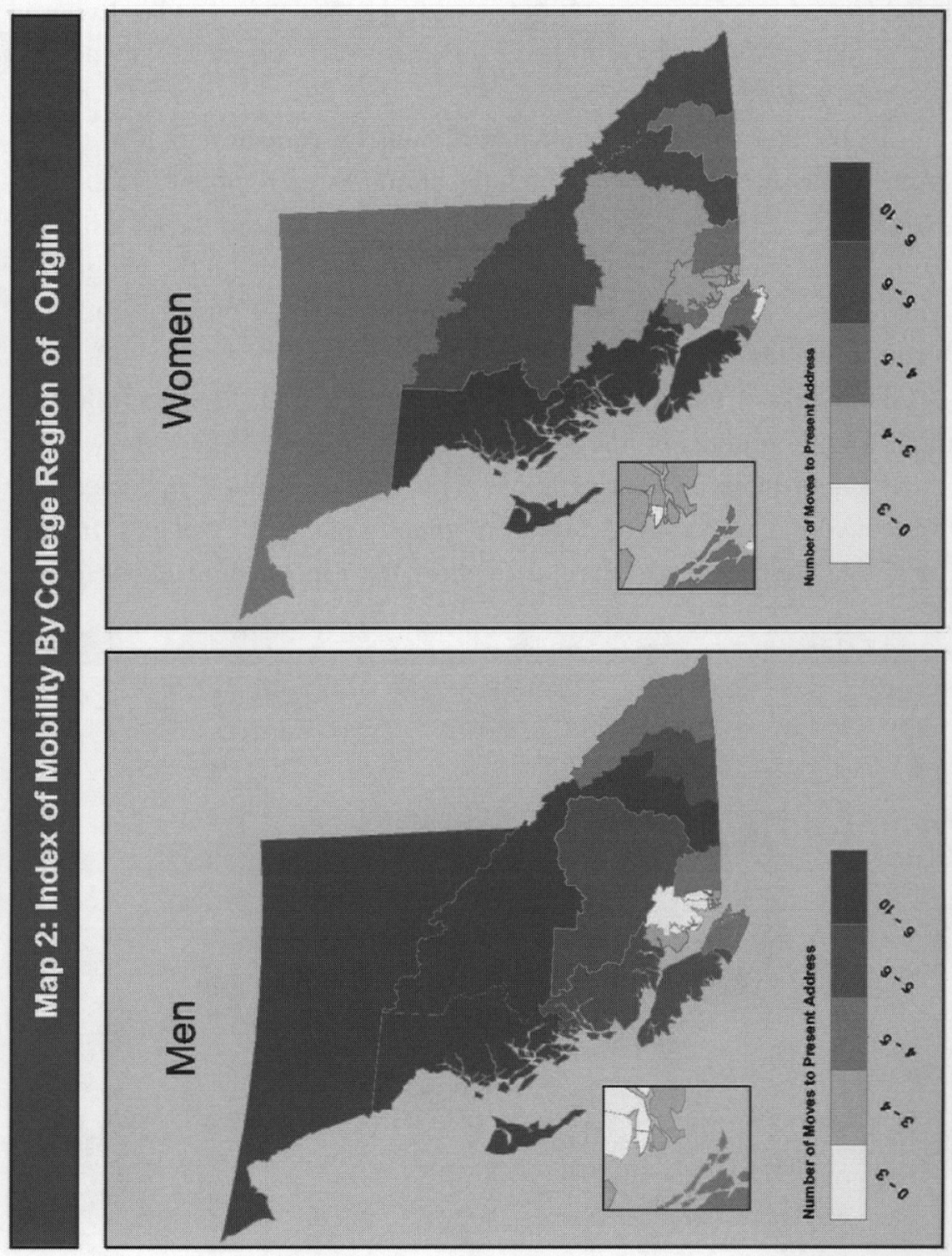

Figure 3: Map 2 - Index of Mobility by College Region of Origin 
experienced by rural areas, coupled with the fact that persons living in urban regions did not have to leave their respective regions to attend post secondary educational institutions.

To better understand regional variations by college region of origin, in the next section, we will highlight briefly three regions-Vancouver, Northwest, and the Okanagan-that display considerably different migrational patterns. The following section will deal with the geographic mobility of current regions with an explicit emphasis on the stability of various regions.

Vancouver College Region. As depicted in Map 3, 10 years following high school graduation, the sample originating from Vancouver was the most stable in terms of migration, with $53 \%$ remaining in Vancouver. Vancouverites who moved did not migrate to many other places. Indeed, of 35 total destinations of the entire cohort, the Vancouver residents moved

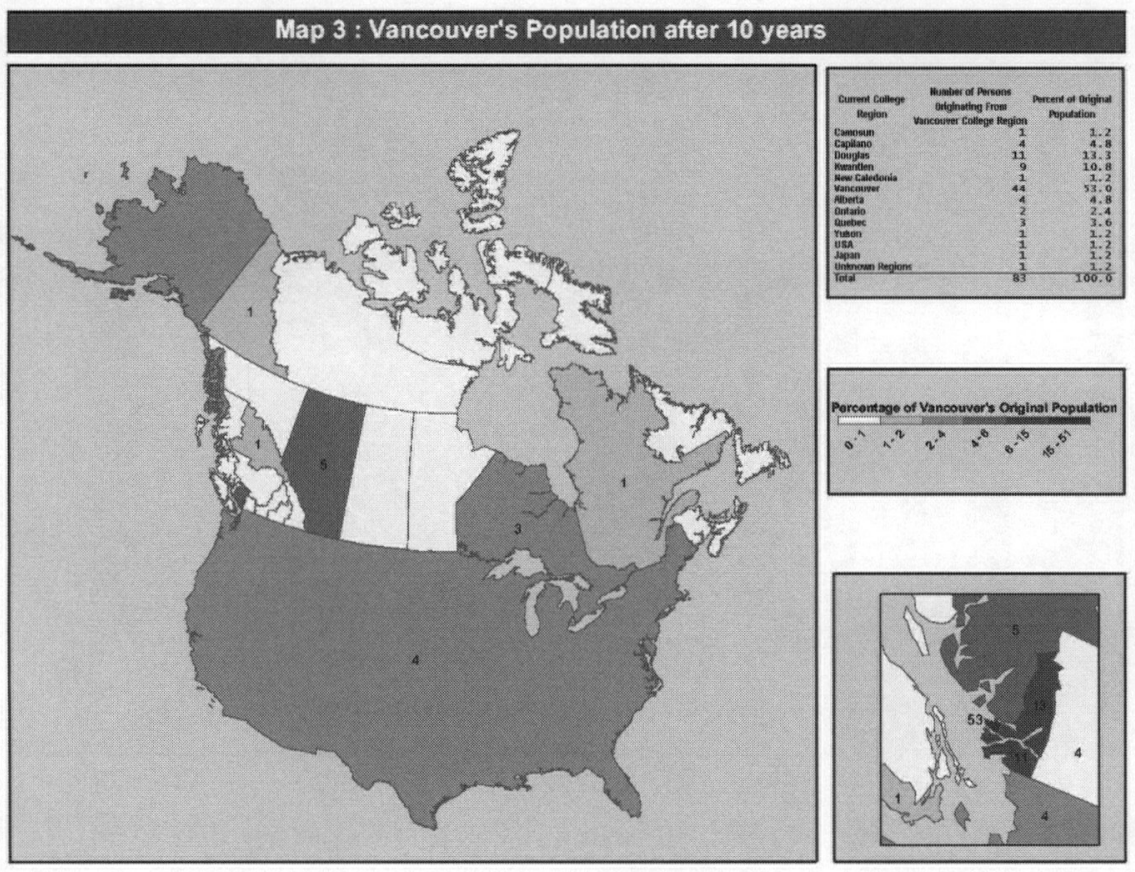

Figure 4: Map 3 - Vancouver's Population After 10 Years 
to only 11 . Most Vancouverites did not stray too far from the Lower Mainland with $82 \%$ of its original population residing in either Vancouver, Douglas, Capilano, or Kwantlen college regions. In 1998, only $2 \%$ of respondents originating from Vancouver were living in different regions within B.C. Five percent of Vancouverites moved to Alberta, $1 \%$ to the Yukon, $1 \%$ to Quebec, $4 \%$ to the U.S., and $1 \%$ to other countries.

Northwest College Region. The Northwest college region was one of the big losers regarding out migration, retaining only $36 \%$ of its original inhabitants (Map 4). In total, 38\% of emigrants moved to the Lower Mainland, with Vancouver taking a $20 \%$ share. Another $14.4 \%$ of exNorthwesters spread to all but three of the remaining 10 college regions, placing it in the middle of the pack in terms of geographic spread. However, in terms of extra-provincial migration, the Northwest region ranked last in terms of geographic spread with their moves limited to Alberta (4\%),

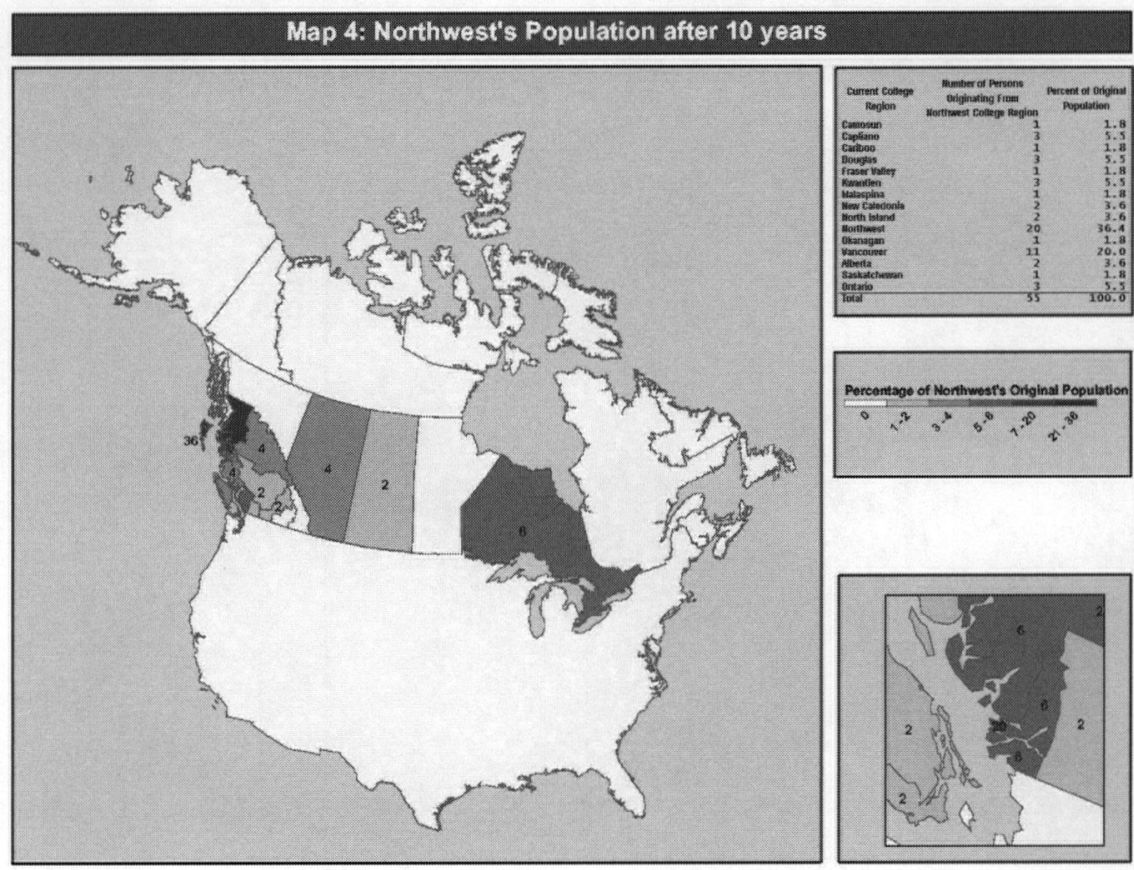

Figure 5: Map 4 - Northwest's Population After 10 Years 
Saskatchewan (2\%), and Ontario (6\%). None of the original Northwest sample lived outside of the country in 1998. Respondents originating from this region moved primarily within B.C., and most often to more urbanized areas of the province. This region is indicative of the general migrational trends occurring in all of the northern regions.

Okanagan College Region. Much like the Northwest region, the Okanagan retained only $38 \%$ of its original population (Map 5). Unlike the Northwest region, respondents who originated from the Okanagan region experienced the greatest geographic spread of any region. By 1998, the 1988 Okanagan sample was most likely to be living either somewhere else in British Columbia or extra-provincially. Twenty-five percent moved to the Lower Mainland and 15\% to other regions in B.C. Not surprisingly, Alberta received a higher proportion (9\%) of persons from the Okanagan region, than did Vancouver. This pattern is shared by all of the Eastern

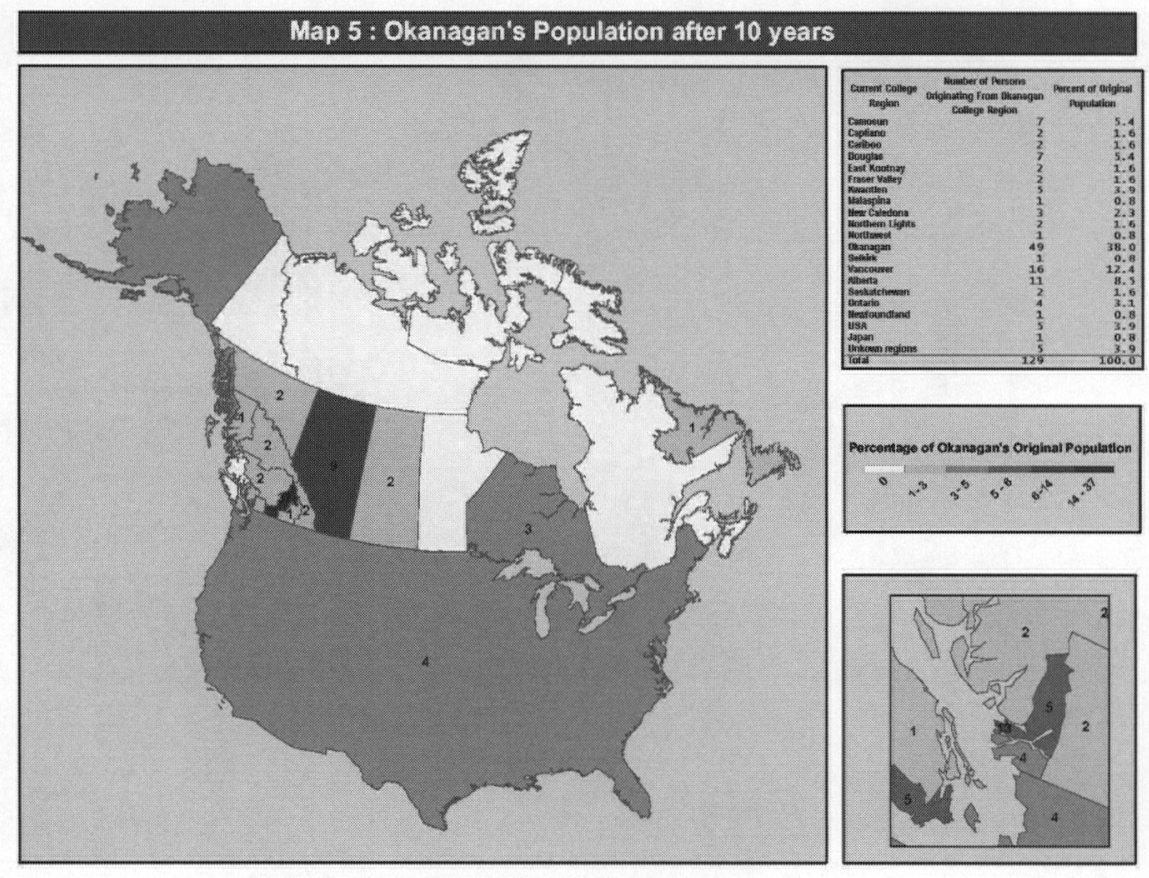

Figure 6: Map 5 Okanagan's Population After 10 Years 
college regions within British Columbia, which all show migrational trends towards Alberta and not towards the Lower Mainland. Ten percent moved to areas outside of either B.C. or Alberta.

Several questions arise from these regional snapshots. Is Vancouver a magnet college region that retains its original population and gains migrants from other areas of the province? Is the flow of migrants from rural B.C. to the Lower Mainland? Did the Vancouver region experience a brain gain as a result of the educated leaving other regions, or did it receive individuals with degrees while simultaneously losing its own? Or did it experience an outflow of individuals with degrees, coupled with an influx of non-degree holders, thus constituting a drain? In the Northwest region, was there a "brain drain" that accompanied the outflow of persons from this region, or were migrants primarily non-degree holders? What are the characteristics of those migrating from the Okanagan region? These issues will be addressed in the last section of the paper.

\section{Geographic Mobility and Current Location of Residence}

Another way of looking at geographic mobility is to determine the number of moves individuals made between communities to arrive at their current destinations. Map 6 depicts the mobility index for current location. It is clear that areas that gained the most immigrants outside of British Columbia (U.S., Alberta, and Ontario), also had the highest levels of mobility. In other words, those who were living in these three locations moved the most to get there. This finding implies that this sub-sample does not tend to stay in a given place for very long. Current residents of the U.S. reported having lived there for an average of only 1.5 years. Those living in Alberta had lived there for an average of four years. Conversely, areas with low levels of mobility, notably the Lower Mainland, also had correspondingly high rates of stability. For instance, current residents of Vancouver reported living there an average 6.5 continuous years. In general, for the Class of 1988, geographic mobility increased in relation to distance away from the Lower Mainland. At the same time, the average length of stay in current location of residence decreased in relation to distance 
from the Lower Mainland. For those living in locations outside of North America, their current length of stay ranged from two months to one year. ${ }^{5}$ It appears that those who moved to extra-provincial locations are more likely to move again than those who had moved to the Lower Mainland. This idea will be further explored in the next section by examining the relationship between educational attainment and geographic mobility.

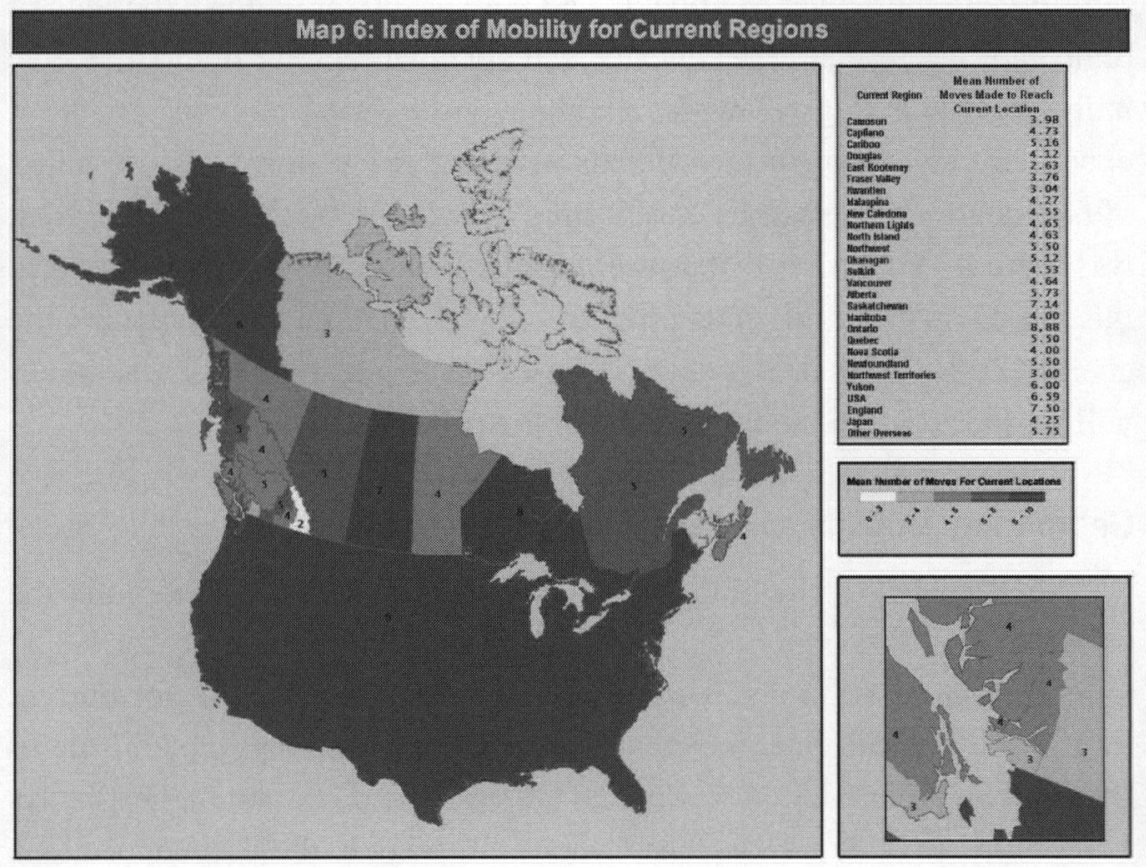

Figure 7: Map 6 - Index of Mobility for Current Regions

\section{Intra-provincial Migration and University Degree Attainment}

The next three maps - degree attainment by original region, proportion of individuals with university degrees by current location, and brain gain or drain (Maps 7, 8, and 9)-and Table 1 highlight the migrational behaviour of this sample in relation to their educational attainment. Map 7 portrays the proportion of individuals who earned bachelors degrees or higher ten years following high school by gender and college region of 
Table 1

1998 Location of Residence by University Degree Attainment

\begin{tabular}{|c|c|c|c|c|c|c|}
\hline & \multicolumn{2}{|c|}{ Females } & \multicolumn{2}{|c|}{ Males } & \multicolumn{2}{|c|}{ Total } \\
\hline & $\begin{array}{c}\text { \# with } \\
\text { univ. } \\
\text { degrees }\end{array}$ & $\%$ & $\begin{array}{c}\text { \# with } \\
\text { univ. } \\
\text { degrees }\end{array}$ & $\%$ & $\begin{array}{c}\text { \# with } \\
\text { univ. } \\
\text { degrees }\end{array}$ & $\%$ \\
\hline Camosun & 14 & 46.7 & 24 & 70.6 & 38 & 59.4 \\
\hline Capilano & 18 & 60.0 & 7 & 50.0 & 25 & 56.8 \\
\hline Cariboo & 13 & 52.0 & 7 & 35.0 & 20 & 44.4 \\
\hline Douglas & 35 & 50.7 & 19 & 42.2 & 54 & 47.4 \\
\hline East Kootenay & 3 & 37.5 & 1 & 9.1 & 4 & 21.1 \\
\hline Fraser Valley & 16 & 50.0 & 5 & 35.7 & 21 & 45.7 \\
\hline Kwantlen & 22 & 36.1 & 15 & 48.4 & 37 & 40.2 \\
\hline Malaspina & 11 & 33.3 & 4 & 28.6 & 15 & 31.9 \\
\hline New Caledonia & 9 & 25.7 & 9 & 42.9 & 18 & 32.1 \\
\hline North Island & 6 & 23.1 & 4 & 44.4 & 10 & 28.6 \\
\hline Northern Lights & 6 & 40.0 & 1 & 20.0 & 7 & 35.0 \\
\hline Northwest & 4 & 21.1 & 4 & 36.4 & 8 & 26.7 \\
\hline Okanagan & 18 & 40.9 & 15 & 48.4 & 33 & 44.0 \\
\hline Selkirk & 4 & 23.5 & 2 & 15.4 & 6 & 20.0 \\
\hline Vancouver & 51 & 57.3 & 50 & 61.0 & 101 & 59.1 \\
\hline Yukon & 2 & 100.0 & 0 & 0.0 & 2 & 100.0 \\
\hline NWT & 0 & 0.0 & 0 & 0.0 & 0 & 0.0 \\
\hline Alberta & 14 & 48.3 & 12 & 46.2 & 26 & 47.3 \\
\hline Saskatchewan & 3 & 75.0 & 1 & 33.3 & 4 & 57.1 \\
\hline Manitoba & 2 & 100.0 & 0 & 0.0 & 2 & 50.0 \\
\hline Ontario & 6 & 50.0 & 8 & 66.7 & 14 & 58.3 \\
\hline Quebec & 2 & 100.0 & 2 & 100.0 & 4 & 100.0 \\
\hline Nova Scotia & 1 & 100.0 & 0 & 0.0 & 1 & 50.0 \\
\hline Newfoundland & 2 & 100.0 & 0 & 0.0 & 2 & 100.0 \\
\hline USA & 12 & 75.0 & 3 & 50.0 & 15 & 68.2 \\
\hline Outside North America & 7 & 77.8 & 4 & 57.1 & 11 & 68.8 \\
\hline Unknown & 1 & 14.3 & 5 & 41.7 & 6 & 31.6 \\
\hline Total & 282 & & 202 & & 484 & \\
\hline
\end{tabular}



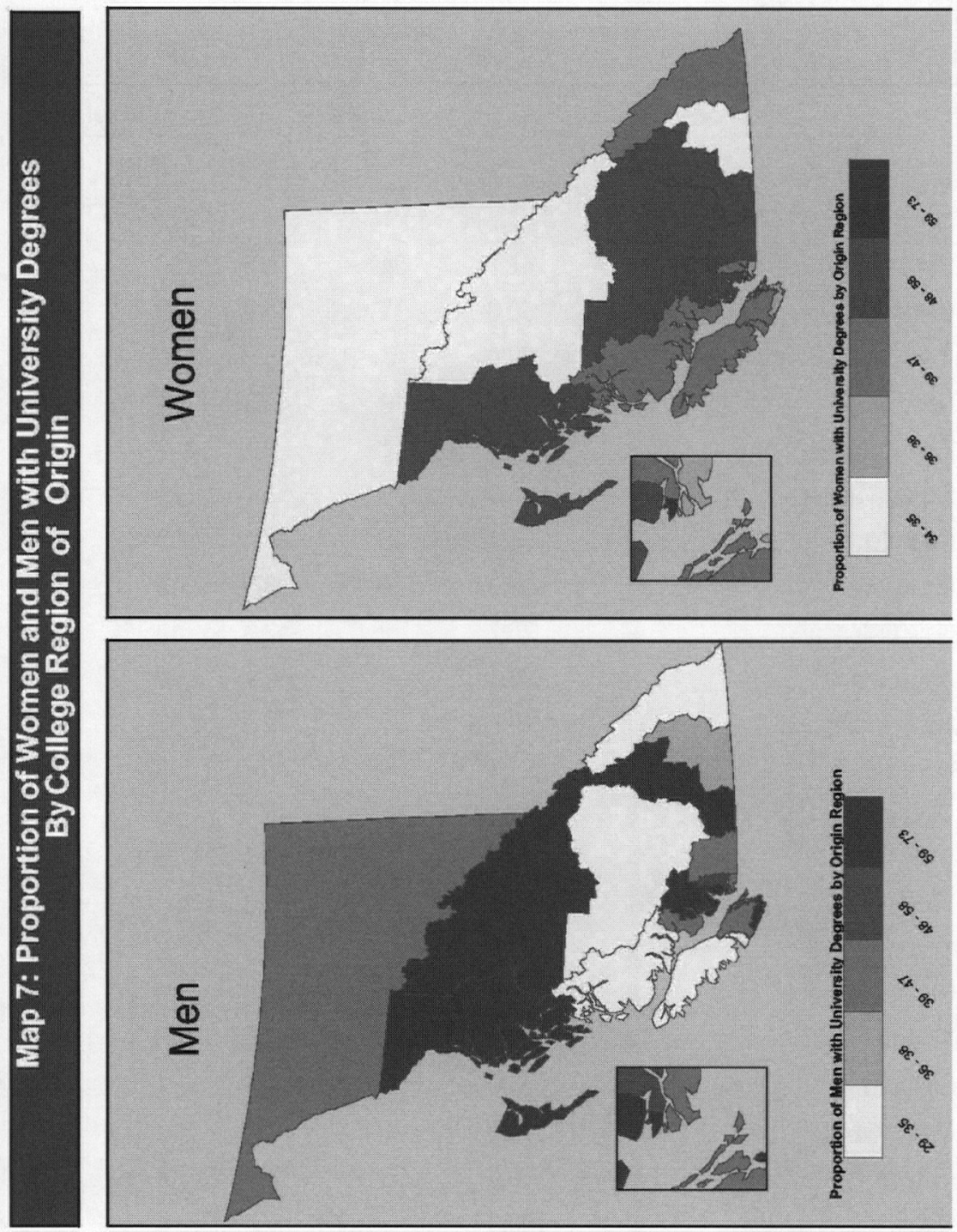

Figure 8: Map 7 - Proportion of Women and Men with University Degrees by College Region of Origin 
origin. For both men and women, there are no concrete trends when it comes to degree attainment. Both rural regions and urban regions are varied in terms of degree attainment. However, gender differences are evident. Nevertheless, this map is limited in that it does not show the current locations of individuals with university credentials. Map 8, documenting the proportion of those with degrees by current location of residence, demonstrates a greater urban-rural split than is evident by examining degree attainment by college region of origin. Not surprisingly, Vancouver and the Lower Mainland all show higher proportions of men with university degrees and the top two-thirds of the province show a lower proportion of men than women with these credentials. For women, the shift was generally in the opposite direction with more degree earners in the south eastern parts of the province.

By comparing the geographic mobility of men and women, it becomes clear that in the north, central, and south eastern portion of the province, higher proportions of women than men have degrees. Along the coast, and in the north, the opposite holds true. This could perhaps be interpreted as two types of geographic flows, where men with degrees migrated to Vancouver and the coast, while women with degrees migrated to the north, central, and southeast part of the province. By examining differences between Maps 7 and 8 , we can demonstrate whether this explanation is plausible and hence demonstrate the more complex dynamics of geographic mobility.

The differences between Maps 7 and 8 are presented in Map 9 which shows intra-B.C. brain gains or drains. For men, brain drain was experienced in almost every region outside the Lower Mainland, but curiously, not the North Island region. The proportion of men living in the North Island region as of 1998 with university degrees increased by $21 \%$ when compared with the proportion of original North Islanders who achieved degrees. However, it is important to point out that of the 23 men originating from the North Island regions, 16 left and seven stayed; in addition, two men moved to this region from other areas. This accounts for a drain of bodies, but a gain in brains.

Similarly, but less surprising, are the results for the Lower Mainland, which show brain gains in all but the Douglas region. Since it was shown 

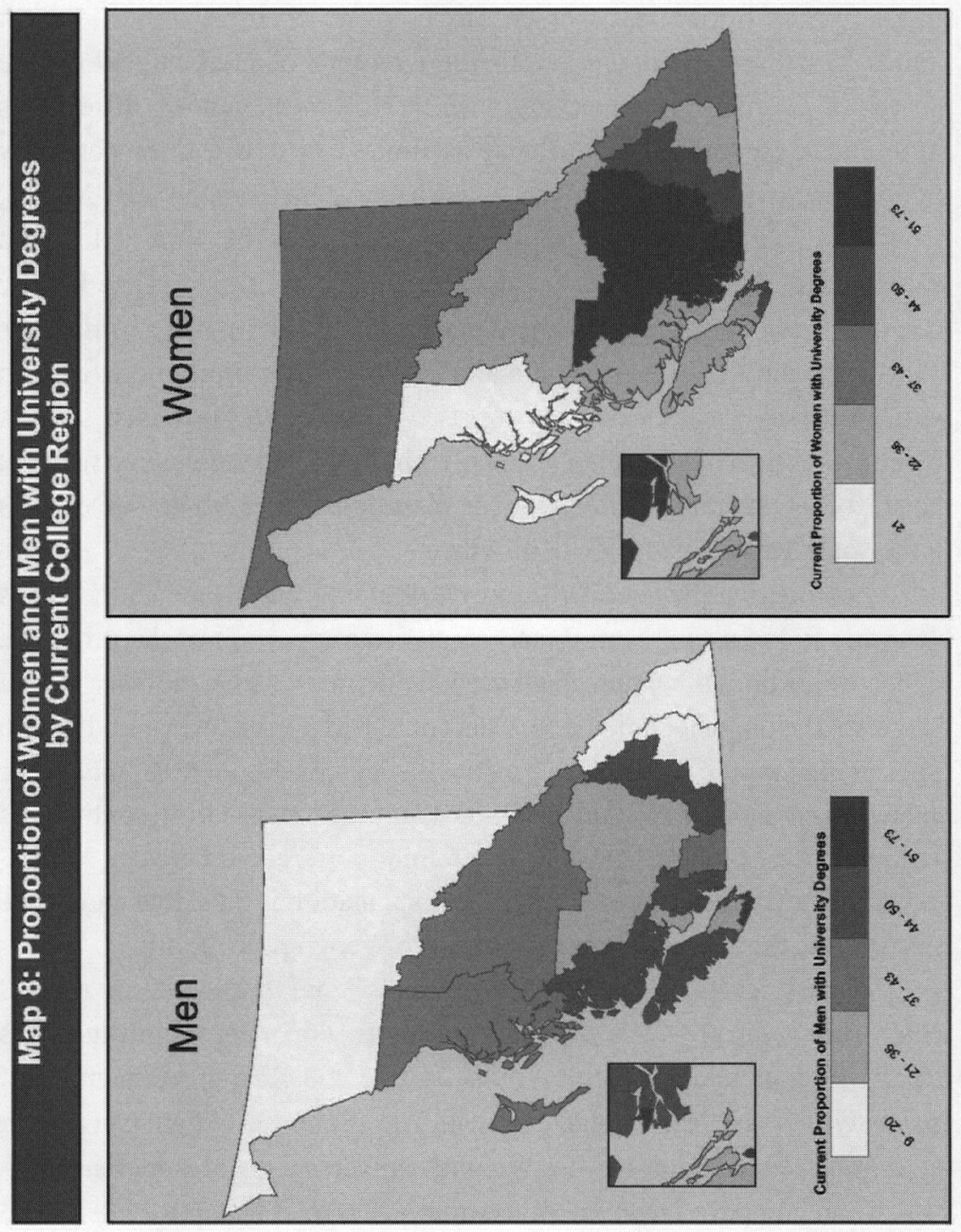

Figure 9: Map 8 - Proportion of Women and Men with University Degrees by Current College Region 


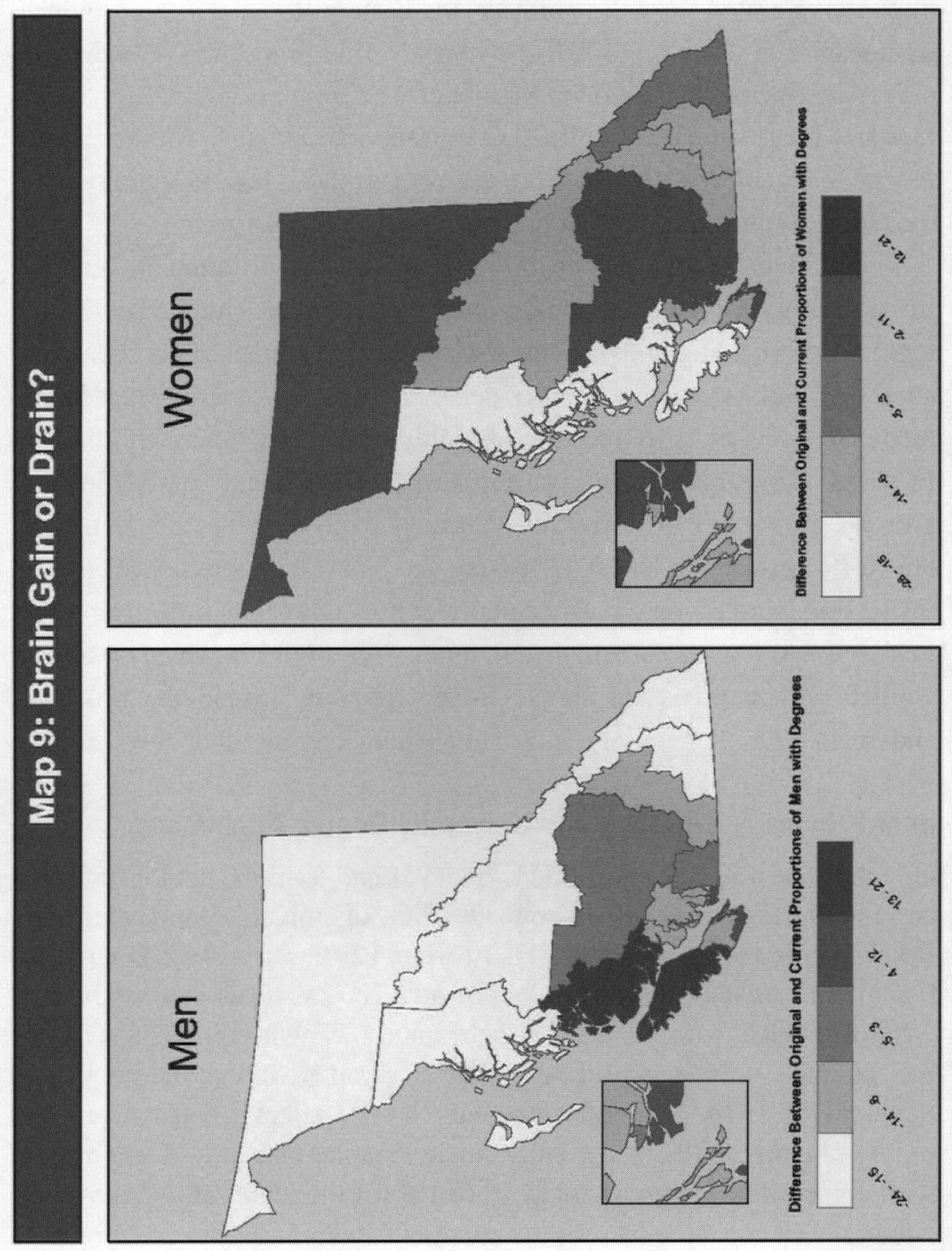

Figure 10: Map 9 - Brain Gain or Drain? 
that men migrated from the northern and eastern regions of the province, it appears that these regions lost a considerable proportion of men with university degrees to the Lower Mainland. The anomaly is the North Island region which was not an intra-B.C. migrational magnet. Although very few people achieved degrees from this region, those few who migrated to the North Island must have earned university degrees.

For women, the geography of migration takes on different dimensions. In most regions, there was not much brain gain. The Fraser Valley region, experiencing an $8 \%$ gain, was the largest winner when it came to attracting women with university degrees. Other regions displayed only mediocre gains in the proportion of highly educated women who moved. In terms of brain drain, the two northern coastal college regions lost the greatest proportion of university educated women, with $28 \%$ departing the Northwest region and $21 \%$ leaving the North Island region. It is very interesting to note women were equally or less likely than men to emigrate in all but two regions in British Columbia. This would suggest two trends: women with degrees are spread more equitably around the province, and men with degrees are more likely concentrate in a few regions.

\section{Inter-Provincial Migration and University Degree Attainment}

The final three maps $(10,11$, and 12) and Table 1 demonstrate the current location of residence outside B.C. of university educated men (Map 10) and women (Map 11). In Map 12, the sample is combined. For men, $2(0.5 \%)$ moved to Quebec and $12(2.8 \%)$ moved to Ontario. Of those, $100 \%$ who moved to Quebec and $67 \%$ who moved to Ontario had attained university degrees. Of the six men living in the United States as of $1998,50 \%$ had university level credentials. However, this represents only $0.7 \%$ of the entire male sample, and only $1.5 \%$ of men with university degrees. In total, $26(6.1 \%)$ of the male sample moved to Alberta; of those, $46 \%$ had earned university degrees. Few with university degrees were living in Saskatchewan (0.7\%). These results concur with findings of other studies and demonstrate that for the Class of 1988, brain drain to the United States is inconsequential. The greater brain drain was to Ontario where $3.9 \%$ of all males with degrees moved, and 


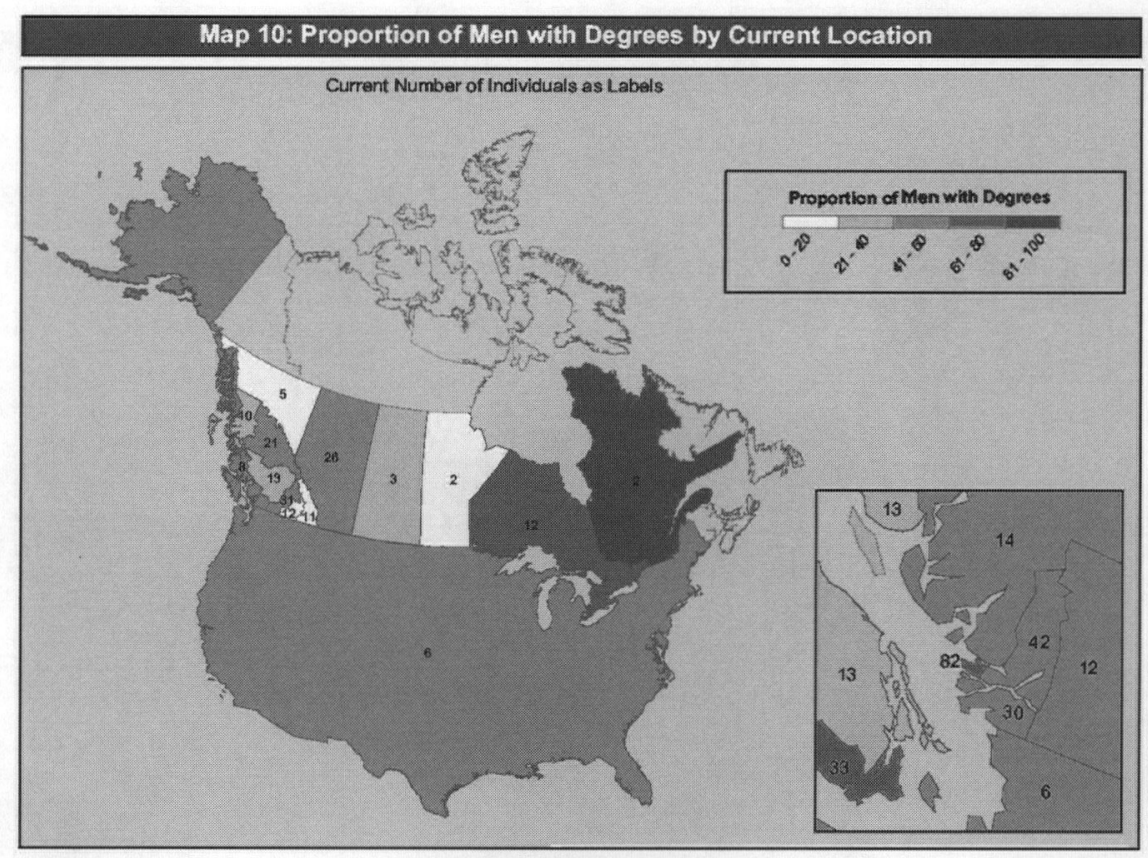

Figure 11: Map 10 - Proportion of Men with Degrees by Current Location

to Alberta where the comparable figure is $5.9 \%$ of men. In total, 7 (1.6\%) of males were living outside North America in 1998 and 57\% (or 2.0\% of all men with degrees) had earned university degrees. For men, brain drain was more of an inter-provincial than an international phenomenon.

The migrational patterns for women with degrees is quite different than that of men. In total, $12(1.9 \%)$ of the female sample moved to Ontario. Of this group, $50 \%$ had earned university degrees (compared with $67 \%$ of men who moved to Ontario). However, when compared with men, higher proportions of women with degrees moved to other provinces or to the United States. Of the 14 (1.7\%) women who moved to the Yukon, the Northwest Territories, Saskatchewan, Manitoba, Newfoundland, Nova Scotia, and Quebec, $86 \%$ had earned degrees. In total, $29(4.7 \%)$ of the women in this study moved to Alberta, of whom $48 \%$ had completed university. In total, $75 \%$ of the 16 women who were living in the U.S. in 1998 had earned degrees, representing $4.2 \%$ of all women in this sample with degrees (and $1.9 \%$ of all women in the 
Map 11: Proportion of Women with Degrees by Current Location

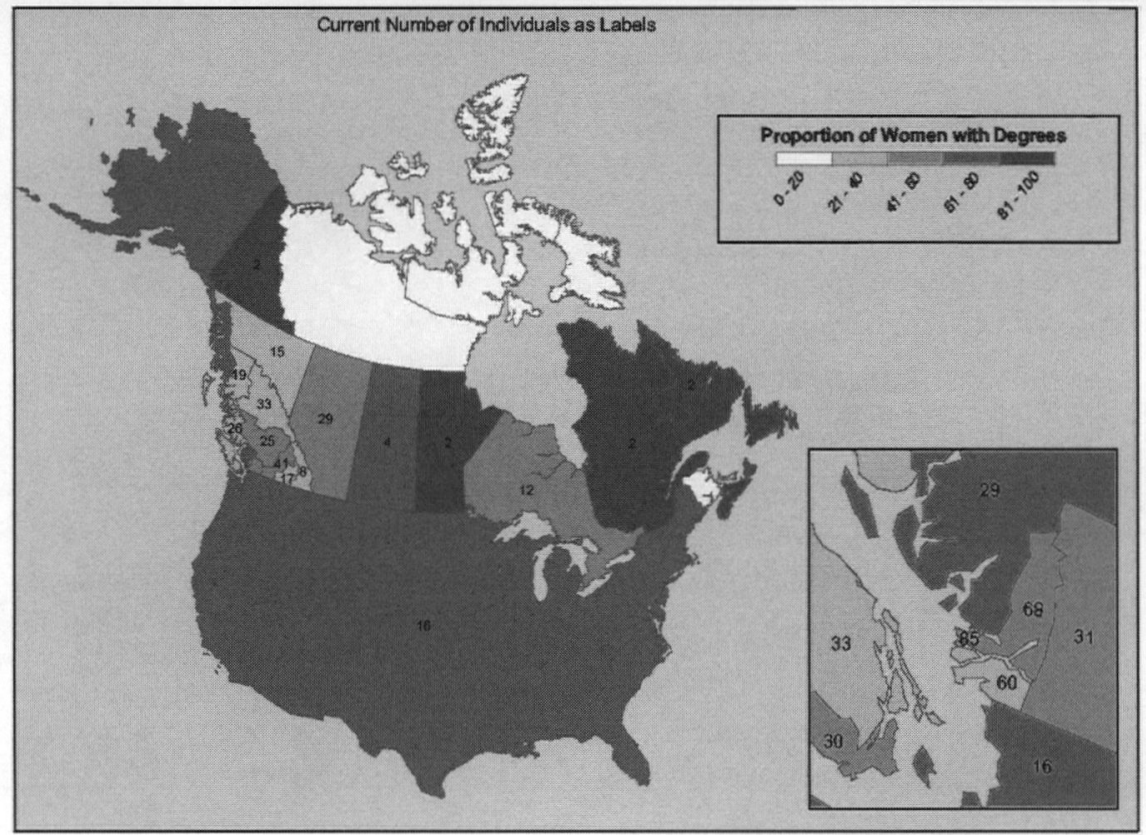

Figure 12: Map 11 - Proportion of Women with Degrees by Current Location

sample). Seventy-seven percent of the 9 (1.5\%) of women who were living overseas 10 years following high school graduation had earned degrees In other words, the vast majority of women living abroad had completed university studies. In almost all instances, women living outside of British Columbia were more likely than men to have earned university degrees.

By combining the female and male samples in a final map (Map 12) and Table 1, it becomes apparent that, in total, $2.1 \%(n=22)$ were living in the United States 10 years following high school. Of those, $68 \%$ had earned university credentials. In addition, $5.3 \%(n=55)$ of the sample were living in Alberta, and $2.3 \%(n=24)$ in Ontario where $47 \%$ and $58 \%$, respectively, had earned university degrees. Other areas in the world gained only a handful (16 or $1.5 \%$ ) of individuals from the 1988 B.C. cohort; of those, $69 \%$ had university degrees. In total, $13.3 \%$ of the Class of 1988 were living outside of British Columbia; of this group, $53 \%$ were university graduates. By 1998, respondents were much more likely be 
living in Vancouver than any other place in North America. Males who had earned degrees tended to move intra-provincially, while university educated women were more likely to move out of province.

Map 12: Proportion of all Persons with Degrees by Current Location

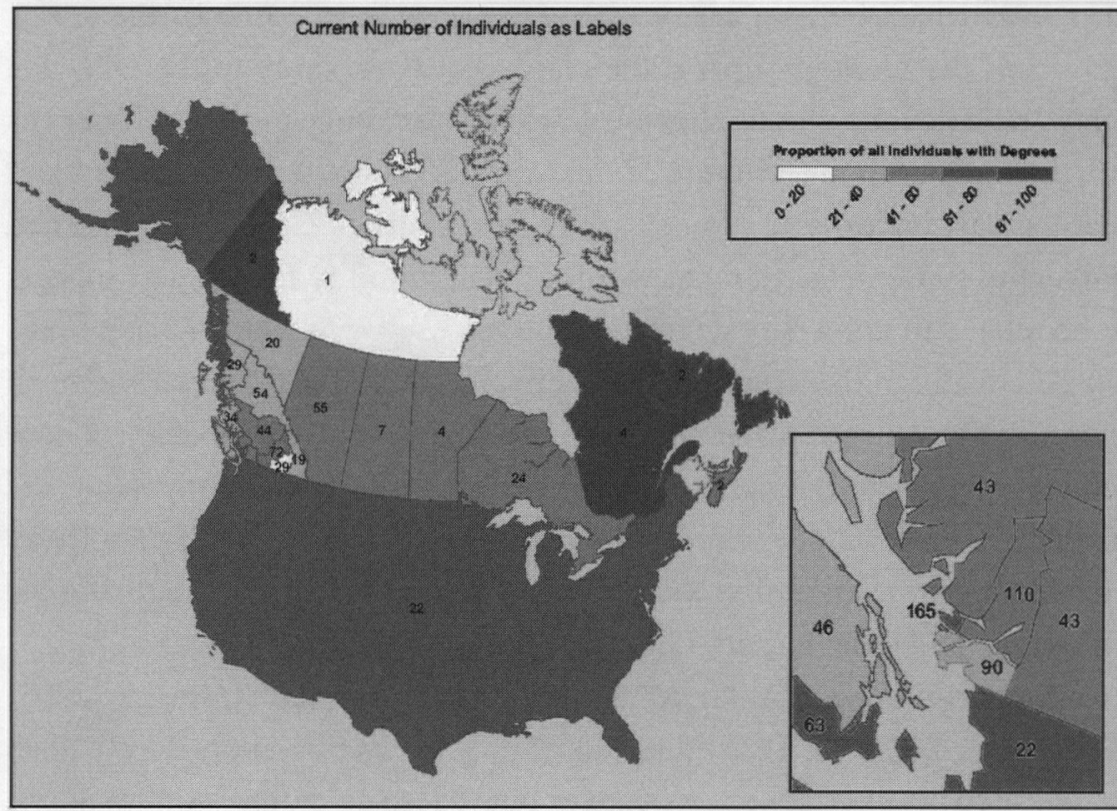

Figure 13: Map 12 - Proportion of All Persons with Degrees by Current Location

\section{DISCUSSION}

Based on these analyses, it appears that for the B.C. Class of 1988, migration patterns are both gendered and geographically complex. The drain, gain, and exchange vary by gender from region to region. Findings of this study challenge the narrow definition of "brain drain" as simply a Canada-U.S.A. issue where Canada's "best and brightest" are lured from Canada. Rather, we are now presented with the challenge of thinking through the implications of intra- and extra-provincial "brain drain" (and gain) primarily within the confines of Canada. 
First, regarding "brain drain" to the U.S., the findings of this study are remarkably consistent with those of other studies. Ten years following high school graduation, only $2.1 \%$ of the Class of 1988 were living in the United States. Of those, $68 \%$ had earned university credentials. This proportion is somewhat higher than that reported by Frank and Bélair (1999) and may be as a result of the ten year time frame of the study. However, the findings support the claim that brain drain to the U.S. is a mere trickle, not a flood. However, when examining gender differences of respondents living in the U.S. and outside North America, it is clear that the vast majority of women who live outside of Canada have earned university credentials. In other words, global mobility for women appears to be related to university degree completion.

The findings also concur with Helliwell (2002) that migrants are much more likely to move to another part of Canada than to another country. Results of this study extend those of other studies by demonstrating the distinctive patterns of migration by region, as evidenced for example, by considerable out-migration to Alberta by individuals originating from the Okanagan and other eastern college regions in B.C.

The results are similar to those of other studies (Garasky, 2002; Kodrzycki, 2001) in that educated young adults are more likely than uneducated young adults to move out of their home communities. According to Garasky (2002), although extensive study of the determinants of migration has been undertaken, "much less is known about how the effects of these determinants differ for urban and rural . . young adults" (p. 414). Because the Paths data set allows for a detailed examination of migration within and beyond British Columbia, our analyses reveal drain and gain from rural to urban regions. The drain of young men - and particularly educated young men - from the northerly regions of B.C. is pronounced. Conversely, women who have earned university degrees are more evenly distributed throughout the province. The next step in our analyses will be to examine the factors that account for differences in urban/rural migration.

According to Voss (2001) "demographic data, tools, and perspectives can evaluate and sometimes overturn popularly held perceptions 
concerning demographic processes" (p. 599). He asserts that "demographic sleuthing" can lead to "myth busting" (p. 599). Through the use of a data set of B.C. young adults containing extensive demographic, social, and educational information, and by employing demographic tools and perspectives, we have provided the foundation for numerous other analyses. This paper has been delimited to providing detailed spatial descriptions of the migration patterns of 1988 B.C. high school graduates. Although it is a first step, it is an important first step, for according to Mulder (2000), "the theory on spatial outcomes is relatively underdeveloped" (p. 426). By analyzing the types and frequency of moves made by this sample of young adults, many other questions emerge. For example, what are the motivating factors behind movers and stayers' migration behaviours? Do these young adults make primarily "productive moves" with the motive of improving family earnings or are moves "consumptive" and intended to improve one's lifestyle and environment (Duncan \& Newman, 1975)? Do motivations differ by gender and college region of origin? Numerous "push" and "pull" factors require further exploration.

Also, Kesselman (2001) points out that there are three types of external costs associated with brain drain - "economic, fiscal, and civic" (p. 78). Although the focus of most discussions on "brain drain" are both U.S. and economically oriented, the civic costs of out-migration from rural communities to other parts of B.C. and beyond can be considered in the same fashion. According to Kesselman, the more educated members of a community are more likely to be active as political and community volunteers and as charitable contributors and philanthropists. Our findings raise questions about the extent to which considerable northern outmigration affects the civic well-being of these communities.

From a higher education perspective, the relationship between the presence of regional post-secondary institutions and migration patterns of young adults is of particular interest. Recommendations from the Macdonald Report, published in 1962, entitled Higher Education in British Columbia, led to the expansion of the B.C. post-secondary system to include two new universities (Simon Fraser University in the Burnaby college region and the University of Victoria in the Camosun region) and 
the creation of a two-year community college in each of 14 college regions throughout the province. According to Macdonald (1962) "the reasons for geographic dispersion of higher education relate primarily to the critical need to seek out and attract to higher education all those who can profit by the experience and by doing so enrich our society. . . . Many potential leaders remain unchallenged by the opportunities for higher education simply because they live in communities where the rewards of intellectual endeavour are not made evident by the presence of a college" (p. 21). Moreover, he claimed that the "ideal of providing suitable higher education for all students who can benefit from it with the ideal of equal opportunity for all students throughout the Province wherever possible" (p. 50).

Although Macdonald did not state explicitly that a goal of educational expansion was to encourage potential leaders to remain in their communities of origin, it should at least be considered as a desirable outcome. Now that the public post-secondary system has expanded further to include 13 degree granting institutions ( 6 universities, 5 university colleges, BCIT, Emily Carr), 13 community colleges and two institutes (see Map A), the possibility of attending a post-secondary institution within one's college region is even more viable. However, are individuals who attend local institutions for at least part of their education more likely to stay or return to their communities of origin? How does transferring out of one's home community to complete university affect eventual geographic destination? What is the relationship among educational attainment, geographic mobility, and occupational opportunities? Also, to what extent does the presence of post-secondary institutions mitigate the drain of brains to other regions in B.C. and beyond? In other words, does the presence of post-secondary institutions within college regions contribute to the civic well-being of these regions? Further analyses will reveal answers to these questions.

\section{Notes}

${ }^{1}$ For example, the Personal Income Tax Data File, which uses addresses provided on individual income tax returns to determine emigration from Canada, 
is described by Finnie (2001) as "probably the most reliable of [the three data sets]" (p. 3). However, according to Zhao et al. (2000), "the only information available on the destinations of movers is the country from which the tax returns are filed" (p. 13); that is, unless individual filers identify themselves as having moved from Canada, they will not be counted as emigrants.

${ }^{2}$ Those who attended private post-secondary institutions, part-time trade courses while working full-time, or apprenticeship programs, as well as those who completed continuing education courses at universities and colleges not leading to degrees or diplomas or non-skills trades vocational programs shorter than three months were not included in this study (Frank \& Bélair, 1999).

${ }^{3}$ When the 1989 respondents $(n=5,345)$ are compared with the original target sample ( $\mathrm{n}=10,000)$, the sample is biased toward women. The original target sample included $52 \%$ females and $48 \%$ males. In $1989,57 \%$ women and $43 \%$ men responded to the Phase I follow-up. When comparing the 1989, 1993, and 1995 follow-ups, the sample has remained remarkably stable in terms of gender composition, age, and geographic location. In 1998, respondents from 71 of 75 school districts existing at the time remained in the study. Over time, however, the proportion of those who had completed academic courses in high school and were eligible for university entrance increased. A table of response rates in relation to a question about post-secondary status in 1989 can be found in Andres (2002a http://www.bccat.bc.ca/pubs/andres2002.pdf). This table demonstrates that university participants in 1989 were more likely to stay in the study over time, and non-participants were not. However, the degree of sample bias does not suggest that the findings of this report cannot be generalized.

${ }^{4}$ To construct the original sample in 1989 , a complicated stratified sampling strategy was employed by assigning individuals into various strata (e.g., geographic region; post-secondary enrolment status immediately following high school graduation). Once assigned to a given stratum, a systematic random selection strategy was employed to generate the sample. Details can be found in Andres (1992).

${ }^{5}$ To protect the identities of respondents, locations are not reported by name.

* The authors wish to acknowledge the support of the Social Science and Humanities Research Council of Canada and the B.C. Council on Admissions and Transfer for funding this longitudinal project. 


\section{References}

Andres, L. (1992). Paths on life's way: Destinations, determinants and decisions in the transition from high school. Unpublished doctoral dissertation. Vancouver: The University of British Columbia.

Andres, L. (2002a). Educational and occupational participation and completion patterns of the Class of '88. Vancouver: British Columbia Council on Admissions and Transfer.

Andres, L. (2002b). Paths on life's way: Base line study (1988) and first followup (1989). Vancouver: Department of Educational Studies, The University of British Columbia.

Andres, L. (2002c). Paths on life's way: Phase II follow-up survey, 1993, five years later (revised). Vancouver: Department of Educational Studies, The University of British Columbia.

Andres, L. (2002d). Paths on life's way: Phase III follow-up survey of 1998, ten years later. Vancouver: Department of Educational Studies, The University of British Columbia.

Anisef, P., Axelrod, P., Baichman-Anisef, E., James, C., \& Turrittin, A. (2000). Opportunity and uncertainty. Life course experiences of the Class of '73. Toronto: University of Toronto Press.

Beauchesne, E. (2001, May 14). It's taking less to lure Canadians south: B.C. study. Vancouver Sun.

Bell, J., Blake, M., Boyle, P.J., Duke-Williams, O., Rees, P., \& Stillwell, J. (2002). Cross-national comparison of internal migration: Issues and measures. Journal of the Royal Statistical Society, 165(3), 435-464.

Bell, M. (1996). How often do Australians move? Alternate measures of population mobility. Australian Population Association, 13(2), 101-124.

Borjas, G.S., Freeman, R.B., \& Katz, L.F. (1996). Searching for the effect of immigration on the labor market. American Economic Review, 86(2), $246-251$.

Boyle, P.J., \& Flowerdew, R. (1993). Modeling sparse interaction matricesInterward migration in Hereford and Worchester, and the underdispersion problem. Environment and Planning, A25(8), 1201-1209.

Boyle, P.J., \& Flowerdew, R. (1997). Improving distance estimates between areal units in migration models. Geographical Analysis, 29(2), 93-107.

Buck, N., \& Scott, J. (1993). She's leaving home: But why? An analysis of young people leaving the parental home. Journal of Marriage and the Family, 55(4), 863-874.

CAUT. (1999). Have we lost our minds? CAUT Education Review, 1(2), 1-11.

Cromartie, P. (2000). Non-metro migration drops in the West and among college graduates. Rural Conditions and Trends, 11(2), 32-38. 
Dahl, G.M. (2002). Mobility and the return to education: Testing a roy model with multiple markets. Econometrica, 70(6), 2367-2420.

Day, K.M., \& Winer, S.L. (1994). Internal migration and public policy: An introduction to the issues and a review of empirical research in Canada. In A.M. Maslove (Ed.), Issues in the taxation of individuals (pp. 3-61). Toronto: University of Toronto Press.

Detang-Dessendre, C., \& Molho, I. (1999). Migration and changing employment status: A hazard function analysis. Journal of Regional Science, 39(1), 103-123.

Dorigo, G., \& Tobler, W. (1983). Push-pull migration laws. Annals of the Association of American Geographers, 73(1), 1-17.

Duncan, G.J., \& Newman, S. (1975). People as planners: The fulfillment of residential expectations. In G.J. Duncan \& J.N. Margan (Eds.), Five thousand American families-Patterns of economic progress. (Vol. 3, pp. 279-318). Ann Arbor: Institute for Social Research, University of Michigan.

Finnie, R. (2001). The brain drain. Myth and reality-What it is and what should be done. Kingston: School of Policy Studies, Queen's University.

Frank, J., \& Bélair, É. (1999). South of the border. Graduates from the Class of '95 who moved to the United States. Ottawa: Statistics Canada.

Garasky, S. (2002). Where are they going? A comparison of urban and rural youths' locational choices after leaving the parental home. Social Science Research, 31(3), 409-431.

Helliwell, J.F. (2002). Checking the brain drain 2000. In G. Hoberg (Ed.), Capacity for choice: Canada in a new North America (pp. 128-156). Toronto: University of Toronto Press.

Johnson, A.D. (1998, September 14). Will surgery fix this brain drain. McLean's, 3.

Johnson, V.J. (2000). Panelist presentation. Paper presented at the Brain Drain, Brain Gain Session Proceedings, Ottawa.

Kesselman, J.R. (2001). Policies to stem the brain drain - without Americanizing Canada. Canadian Public Policy, 27(1), 77-93.

Kodrzycki, Y.K. (2001). Migration of recent college graduates: Evidence from the National Longitudinal Survey of Youth. New England Economic Review, Jan/Feb., 13-31.

Leblanc, D. (1999, August 28). Brain drain study finds the best are more likely to leave. Globe and Mail.

Macdonald, J.H. (1962). Higher education in British Columbia. Vancouver: The University of British Columbia.

Mahroum, S. (2000). Highly skilled globetrotters: Mapping the international migration of human capital. $R \& D$ Management, 30(1), 23-31. 
Michalos, A.C. (1997). Migration and the quality of life: A review essay. Social Indicators Research, 39(2), 121-167.

Morokvasic, M. (1996). Movement of scientific elites from the other Europe: Exodus or circulation? Revue D'Études Comparatives Est-Ouest, 27(3), 31-75.

Mulder, C.H., \& Clark, W.A.V. (2000). Leaving home and leaving the state: Evidence from the United States. International Journal of Population Geography, 6, 423-437.

Murray, S. (2000). Panelist presentation. Paper presented at the Brain Drain, Brain Gain Session Proceedings, Ottawa.

Oleck, J., \& Weber, J. (1998, February 11). Will surgery fix this brain drain? Business Week.

Partridge, M.D., \& Rickman, D.S. (1999). A note on the benefits to current residents of state employment growth: Is there an industry mix effect on migration? Journal of Regional Science, 39(1), 167-181.

Shakir, U. (2000). Panelist presentation. Paper presented at the Brain Drain, Brain Gain Session Proceedings, Ottawa.

Stimson, R.J., \& Minnery, J. (1998). Why people move to the "sun-belt": A case study of long-distance immigration to the Gold Coast, Australia. Urban Studies, 35(2), 193-214.

Sweeney, S.H., \& Konty, K.J. (2002). Population forecasting with nonstationary multiregional growth matrices. Geographical Analysis, 34(4), 289-312.

Torjman, S. (2000). Panelist presentation. Paper presented at the Brain Drain, Brain Gain Session Proceedings, Ottawa.

Treyz, G.I., Rickman, D.S., Hunt, G.L., \& Greenwood, M.J. (1993). The dynamics of the United States internal migration. Review of Economics and Statistics, 75(2), 209-214.

Voss, P.R., Hammer, R.B., \& Meier, A.M. (2001). Migration analysis: A case for local public policy. Population Research and Policy Review, 20(6), $587-603$.

Whittington, L., \& Peters, H.E. (1996). Economic incentives for financial and residential independence. Demography, 33, 82-97.

Wright, R.A., Ellis, M., \& Reibel, M. (1997). The linkage between immigration and internal migration in large metropolitan areas in the United States. Economic Geography, 73(2), 234-254.

Zhao, J., Drew, D., \& Murray, T.S. (2000). Brain drain and brain gain: The migration of knowledge workers from and to Canada. Education Quarterly Review, 6(3), 8-35. 